Pesq. Vet. Bras. 36(7):595-599, julho 2016 DOI: $10.1590 /$ S0100-736X2016000700006

\title{
Detection of enteric viruses in pancreas and spleen of broilers with runting-stunting syndrome (RSS) ${ }^{1}$
}

\author{
Luis Fabian N. Nuñez ${ }^{2}$, Silvana H. Santander Parra² ${ }^{2}$ Claudete S. Astolfi-Ferreira², \\ Claudia Carranza ${ }^{3}$, David I.D. De La Torre ${ }^{2,4}$, Antonio C. Pedroso ${ }^{5}$ \\ and Antonio J. Piantino Ferreira ${ }^{3 *}$
}

\begin{abstract}
Nuñez L.F.N., Santander Parra S.H., Astolfi-Ferreira C.S., Carranza C., De La Torre D.I.D., Pedroso A.C. \& Ferreira A.J.P. 2016. Detection of enteric viruses in pancreas and spleen of broilers with runting-stunting syndrome (RSS). Pesquisa Veterinária Brasileira 36(5):595-599. Departamento de Medicina Veterinária Preventiva e Saúde Animal, Faculdade de Medicina Veterinária e Zootecnia, Universidade de São Paulo, Av. Prof. Dr. Orlando Marques de Paiva 87, São Paulo, SP 05508-270, Brazil. E-mail: ajpferr@usp.br

Enteric disease is a multifactorial problem in chickens, which causes gastrointestinal alterations, elevated feed conversions and impairment. In the last years, several enteric viruses were implicated in enteric disease; case reports have shown their presence alone or in concomitant infections during outbreaks and have suggested that they might be determining factors in the aetiology of enteric disease. This study shows high detection rates of enteric viruses in the pancreas and spleen in samples from an outbreak of enteritis and malabsorption in 16 chicken flocks ( $\mathrm{n}=80$ broilers). Avian nephritis virus (ANV) was the most ubiquitous virus, present in $75 \%$ of the flocks followed by avian rotavirus group A (ART-A) with $68.75 \%$, and by chicken astrovirus (CAstV) and chicken parvovirus (ChPV) in $43.75 \%$ of samples. Viruses were present in the pancreas of positive flocks at extremely high rates: $100 \%$ for ART-A, $91.7 \%$ for ANV, 100\% for CAstV and $57.14 \%$ for ChPV. By contrast, only $16.7 \%$ and $57.14 \%$ of intestine samples were positive for ANV and CAstV, respectively. Avian reovirus (AReo) and avian adenovirus group 1 (FAdV-1) were not detected. These results suggest that high viral detection rates in pancreas samples may be a result of viremia during enteric disease, with subsequent damage of the exocrine pancreas, leading to runting-stunting syndrome (RSS).
\end{abstract}

INDEX TERMS: Broiler, enteric viruses, detection, pancreas, spleen, runting-stunting syndrome, RSS.

RESUMO.- [Detecção de vírus entéricos em pâncreas e baço de frangos com a síndrome de nanismo e raquitismo (RSS).] A doença entérica é um problema multifatorial em galinhas que causa alterações gastrointestinais, conversão alimentar elevada e deficiência de crescimento.

\footnotetext{
${ }^{1}$ Received on July 27, 2015.

Accepted for publication on April 19, 2016.

${ }^{2}$ Departamento de Patologia, Faculdade de Medicina Veterinária e Zootecnia (FMVZ), Universidade de São Paulo (USP), São Paulo, SP 05508270, Brazil.

${ }^{3}$ Departamento de Medicina Veterinária Preventiva e Saúde Animal (VPS), FMVZ-USP, São Paulo, SP 05508-270, Brazil. *Corresponding author: ajpferr@usp.br

${ }^{4}$ Faculdad de Medicina Veterinaria y Zootecnia, Universidad Central del Ecuador, Quito, Ecuador.

${ }^{5}$ Departamento de Medicina Veterinária, Faculdade de Medicina Veterinária e Zootecnia, Universidade Federal da Fronteira Sul (UFFS), BR-182 Km 466, Realeza, PR 85770-000, Brazil.
}

Nos últimos anos, os vírus entéricos foram associados à doença entérica; casos reportados mostraram a infecção de um único vírus e também infecções concomitantes durante os surtos sugerindo a presença de múltiplos fatores etiológicos nas doenças entéricas. Este estudo mostra uma alta taxa de detecção dos vírus entéricos em amostras de pâncreas e baço de um surto de enterite e má-absorção em 16 lotes de frangos ( $\mathrm{n}=80$ frangos). 0 vírus de nefrite aviária (ANV) foi o vírus mais detectado, estando presente em $75 \%$ dos lotes seguido pelo rotavírus aviário grupo A (ART-A) em 68,75\% dos casos, e pelo astrovirus (CAstV) e parvovírus aviários (ChPV), ambos em 43,75\% das amostras. Os vírus estavam presentes no pâncreas dos lotes positivos em percentuais elevados: 100\% para ART-A e CAstV; $91,7 \%$ para ANV, e em $57,14 \%$ para ChPV. Em contraste, somente $16,7 \%$ e $57,14 \%$, em amostras de intestino, foram positivos para ANV e CAstV, respectivamente. Reovírus aviário 
(AReo) e o adenovírus do grupo 1 (FAdV-1) não foram detectados. Estes resultados sugerem que os elevados percentuais de vírus detectados em amostras de pâncreas podem estar associados à viremia durante a doença entérica, com subsequente lesão no pâncreas exócrino das aves levando ao desenvolvimento da síndrome de nanismo e raquitismo.

TERMOS DE INDEXAÇÃO: Frangos, vírus entéricos, detecção, pâncreas, baço, síndrome de nanismo e raquitismo, RSS.

\section{INTRODUCTION}

Enteric disease in poultry is a multifactorial problem that is not fully understood. This disorder (also known as malabsorption syndrome and as runting-stunting syndrome or RSS) is a multifactorial disease of chickens which results in gastrointestinal alterations along with elevated feed conversion and decreased body weight (Rebel et al. 2006, Saif 2013, Nuñez et al. 2016a, Nuñez et al. 2016b). Bacterial, protozoal and viral agents are known to be involved in the development of outbreaks, which are also related to flock management and to the immunological status of flocks (Nuñez \& Ferreira 2013, Moura-Alvarez et al. 2013, Moura-Alvarez et al. 2014). In the last years, enteric viruses, such as chicken astrovirus (CAstV), chicken parvovirus (ChPV), avian rotavirus (ART), fowl adenovirus type I (FAdV I) and avian reovirus (AReo) have been increasingly implicated. This report is showing its presence alone or in concomitant infections during outbreaks and suggesting that they play an important role in the aetiology of enteric disease (Zsak et al. 2013). These recent reports have led to the development of experimental models to recreate the disease and to try to determine its etiopathogenicity (Zsak et al. 2013, Decaesstecker et al. 1989, Nuñez et al. 2015a). However, due to the complex nature of this disease, the exact aetiology remains unknown.

The objective of this study was to detect viruses associated with RSS in Brazilian commercial chicken flocks.

\section{MATERIALS AND METHODS}

Description of the problem. In late 2012, 16 broiler flocks from the state of Minas Gerais, Brazil, were reported to be excreting undigested feed and aqueous feces and to be exhibiting delayed growth and increased mortality, at variable rates. Necropsy revealed severe congestion of the duodenal walls compatible with duodenitis, and runting-stunting syndrome (RSS) was mooted.
Sampling. Five broilers aged 8 to 28 days randomly, chosen from each affected flock described above, were submitted to the Avian Diseases Laboratory at the FMVZ-USP, São Paulo/SP, Brazil, giving a total of 80 birds analyzed. A separate pool of each organ (gastrointestinal tract, spleen or pancreas) was obtained from the five sampled birds from each flock, so were collected 16 samples (pool) of intestinal tract, 16 samples (pool) of pancreas and 10 samples (pool) of spleen, giving a total of 42 samples, all samples were submitted to molecular analyses for the presence of enteric viruses.

Nucleic acid extraction for viral detection. Tissues from the intestine, pancreas or spleen of five (05) birds of each flock were pooled separately and homogenized; pooled samples from each tissue type and from each flock were homogenized separately and diluted in 1.5-mL microcentrifuge tubes containing $0.1 \mathrm{M}$ sterile PBS, pH 7.4, at a 1:1 proportion. These diluted samples were then frozen at $-20^{\circ} \mathrm{C}$ for 10 minutes and thawed at $56^{\circ} \mathrm{C}$ for 1 minute, and this process was repeated three times, including homogenization between freeze-thaw cycles and vortexing for 20 seconds. For DNA extraction, the samples were centrifuged at $12.000 \mathrm{xg}$ for 20 minutes at $4^{\circ} \mathrm{C}$, and for RNA extraction, the samples were centrifuged for 30 minutes under the same conditions. The resulting supernatants were stored at $-20^{\circ} \mathrm{C}$ until analysis. DNA and RNA were extracted from the supernatants using TRIzol ${ }^{\circledR}$ (Invitrogen, Valencia, CA, USA) according to the manufacturer's instructions.

PCR and RT-PCR detection of viral agents. The screening procedures performed to detect the most common enteric viruses in Brazilian flocks (Moura-Alvarez et al. 2013) included polymerase chain reaction (PCR) assays for the detection of avian adenovirus group 1 (FAdV-1) (Meulemans et al. 2001) and chicken parvovirus (ChPV) (Zsak et al. 2009) and RT-PCR analysis for chicken astrovirus (CAstV), avian nephritis virus (ANV), avian rotavirus group A (ART-A) (Day et al. 2007) and Avian reovirus (AReo) (Pantin-Jackwood et al. 2008). Target genes, primers and amplicon sizes are listed in Table 1. ChPV, FAdV-1, CAstV and ANV strains previously isolated from Brazilian flocks and whose identity was confirmed by sequencing were used as positive controls in the molecular assays. Additionally, Nebraska calf diarrhoea virus and the S1133 strain were used as controls for rotavirus and reovirus, respectively.

\section{RESULTS}

Table 2 shows the detection rates of the screened viruses. All flocks that presented enteric problems were positive for at least one of these pathogens. Avian nephritis virus (ANV) and avian rotavirus group A (ART-A) were present in more than $60 \%$ of the flocks ( $75 \%$ and $68.75 \%$, respectively). Both chicken astrovirus (CAstV) and chicken parvovirus (ChPV)

Table 1. Primer sequences, amplicon sizes for RT-PCR and PCR assays performed to detect enteric viruses in chickens with RSS in Brazil

\begin{tabular}{|c|c|c|c|c|}
\hline Virus & Target gene & Primer name & Primer sequence $\left(5^{\prime}-3^{\prime}\right)$ & Amplicon size (bp) \\
\hline \multirow[t]{2}{*}{ Avian rotavirus group $\mathrm{A}$} & \multirow[t]{2}{*}{ NSP4 } & NSP4-F30 & GGG CGT GCG GAA AGA TGG AGA AC & \multirow[t]{2}{*}{630} \\
\hline & & NSP4-R660 & GGG GTT GGG GTA CCA GGG ATT AA & \\
\hline \multirow[t]{2}{*}{ Avian nephritis virus } & \multirow[t]{2}{*}{ Polymerase } & ANV pol 1F & GYT GGG CGC YTC YTT TGA YAC & \multirow[t]{2}{*}{473} \\
\hline & & ANV pol 1R & CRT TTG CCC KRT ART CTT TRT & \\
\hline \multirow[t]{2}{*}{ Chicken astrovirus } & \multirow[t]{2}{*}{ Polymerase } & CAS pol 1F & GAY CAR CGA ATG CGR AGR TTG & \multirow[t]{2}{*}{362} \\
\hline & & CAS pol 1R & TCA GTG GAA GTG GGK ART CTA C & \\
\hline \multirow[t]{2}{*}{ Chicken parvovirus } & \multirow[t]{2}{*}{ NS } & PVF1 & TTC TAA TAA CGA TAT CAC TCA AGT TTC & \multirow[t]{2}{*}{561} \\
\hline & & PVR1 & TTT GCG CTT GCG GTG AAG TCT GGC TCG & \\
\hline \multirow[t]{2}{*}{ Avian reovirus } & \multirow[t]{2}{*}{ S4 } & S4-F13 & GTG CGT GTT GGA GTT TCC CG & \multirow[t]{2}{*}{1120} \\
\hline & & S4-R1133 & TAC GCC ATC CTA GCT GGA & \\
\hline \multirow{2}{*}{$\begin{array}{l}\text { Avian adenovirus } \\
\text { group } 1\end{array}$} & \multirow[t]{2}{*}{ Hexon } & Hexon A & CAA RTT CAG RCA GAC GGT & \multirow[t]{2}{*}{897} \\
\hline & & Hexon B & TAG TGA TGM CGS GAC ATC AT & \\
\hline
\end{tabular}


Table 2. Viral detection in each flock and the presence of concomitant infections

\begin{tabular}{|c|c|c|c|c|c|c|c|}
\hline \multirow{2}{*}{$\begin{array}{c}\text { Flock } \\
\text { designation }\end{array}$} & \multicolumn{6}{|c|}{ Detected viruses } & \multirow{2}{*}{$\begin{array}{c}\text { Number of viruses } \\
\text { detected }\end{array}$} \\
\hline & ANV & ART-A & CAstV & ChPV & AReo & FAdV-I & \\
\hline $9^{*}$ & $\mathrm{P}$ & - & - & - & - & - & 1 virus \\
\hline $15^{*}$ & P-I & - & - & - & - & - & 1 virus \\
\hline 6 & - & - & P-I & - & - & - & 1 virus \\
\hline 7 & - & P-S & - & - & - & - & 1 virus \\
\hline $14^{*}$ & $\mathrm{P}$ & $\mathrm{P}$ & - & - & - & - & 2 viruses \\
\hline 10 & P-S & - & - & $\mathrm{P}$ & - & - & 2 viruses \\
\hline 11 & $P$ & P-S & - & - & - & - & 2 viruses \\
\hline 16 & - & P-S & - & $\mathrm{S}$ & - & - & 2 viruses \\
\hline $5^{* *}$ & - & $\mathrm{P}$ & P-I & - & - & - & 3 viruses \\
\hline 8 & I & - & P-S-I & $\mathrm{S}$ & - & - & 3 viruses \\
\hline $13^{*}$ & $P$ & $P$ & - & $\mathrm{P}$ & - & - & 3 viruses \\
\hline 1 & P-S & P-S & P-S-I & - & - & - & 3 viruses \\
\hline 2 & $\mathrm{P}$ & P-S & P-S & - & - & - & 3 viruses \\
\hline 4 & P-S & P-S & - & $\mathrm{P}$ & - & - & 3 viruses \\
\hline 12 & $\mathrm{P}$ & P-S & P-S & P-S & - & - & 4 viruses \\
\hline $3^{*}$ & $P$ & $\mathrm{P}$ & $\mathrm{P}$ & $\mathrm{P}$ & - & - & 4 viruses \\
\hline Total & $12(75 \%) 1$ & $11(68.75 \%) 1$ & $7(43.75 \%) 1$ & $7(43.75 \%) 1$ & $0(0) 1$ & $0(0) 1$ & \\
\hline
\end{tabular}

*Percentages (in parentheses) were calculated based on the number of positives vs. the number of samples for each virus. $\mathrm{P}=$ pancreas; $\mathrm{S}=$ spleen; $\mathrm{I}=$ intestine. ${ }^{* *}$ Samples sent without spleen.

Table 3. Distribution of enteric viruses in tissues of naturally infected broiler chickens

\begin{tabular}{lccccccccc}
\hline Organs & \multicolumn{4}{c}{ Number of positive samples for each virus (\%)* } & \multirow{2}{*}{ Total positive samples } \\
& \multicolumn{2}{c}{ ART-A } & \multicolumn{2}{c}{ ANV } & \multicolumn{2}{c}{ CAstV } & \multicolumn{2}{c}{ ChPV } & \\
for each tissue**
\end{tabular}

*Percentages (in parentheses) were calculated based on the number of positive tissue samples vs. the number of positive flocks for each virus. ${ }^{* *}$ Number of positive samples per total number of samples tested.

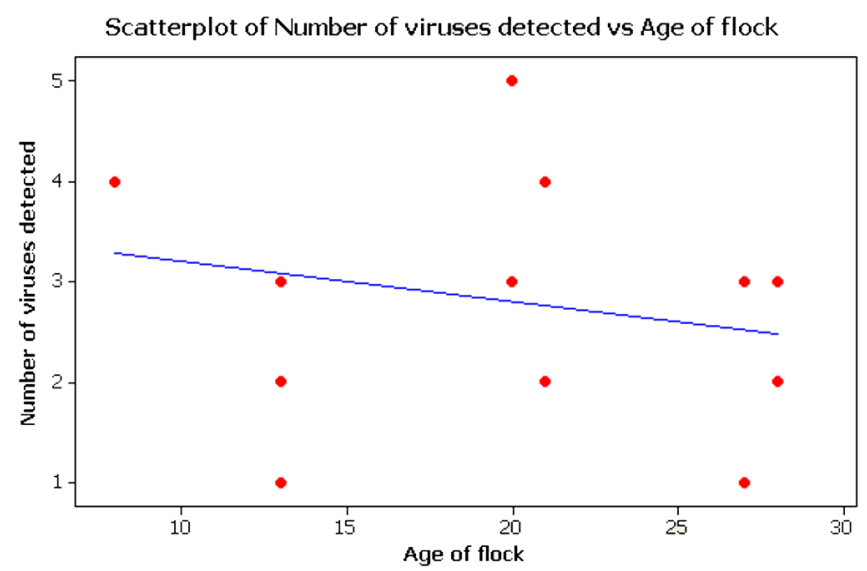

Fig.1. Regression analysis showing the relationship between the ages of birds and the molecular detection of viral agents. A result of $p>0.05$ indicated that there was no relation between the ages of birds and the molecular detection of enteric pathogens in these sampled flocks.

were both detected in $43.75 \%$ of the samples; while no avian reovirus (AReo) or avian adenovirus group 1 (FAdV-1) was detected. In addition, as expected, concomitant infection with two or more viruses were observed in most flocks (75\%), and single viral infections were observed in only $25 \%(n=4)$ of the flocks. Notably, in the 4 flocks with single viral infections, the main organ in which virus was detected was the pancreas. In general, the pancreas was the organ in which viruses were detected at the highest rates; 33 out of 37 (89.1\%) pancreas samples were positive, by contrast only 6 of 37 (16.2\%) pooled intestine samples were positive for the presence of at least one enteric virus. Enteric viruses were also detected at high rates in spleen samples from the different flocks; $77.3 \%$ of all spleen samples were positive for at least one virus (Table 3). Finally, a regression analysis (Minitab ${ }^{\circledR}$ software) showed no relationship between the age of birds (8-28 days) and the molecular detection of one or more enteric pathogens (Fig.1).

\section{DISCUSSION}

In this case of severe duodenitis and RSS in 16 broiler flocks, molecular analysis showed that concomitant infection with 2 or 4 viruses were detected in $75 \%$ of the flocks, while single viral infections were detected in the remaining $25 \%$ of the flocks. Analysis revealed that the prevalence of viruses such as avian nephritis virus (ANV), avian rotavirus group A (ART-A), chicken astrovirus (CAstV) and chicken parvovirus (ChPV) were high among broilers with digestive disorders. These results are consistent with previous reports from Brazil and from several other poultry-producing countries, where enteric problems and growth retardation are often linked to the detection of one or more of these enteric viruses (Otto et al. 2012, Koo et al. 2013, Villarreal et al. 2006) and support the hypothesis that RSS has a multifactorial aetiology. Despite of a strong relationship between pathogen detection and the development of the disease the diagnoses has not been clearly established (Koo et al. 2013). Notwithstanding, the diversity of viruses detected during outbreaks, variations in virulence among 
serotypes or strains, or similarities in the signs and lesions are observed (Saif 2013). Thereby, concomitant infections are more likely to have a detrimental, synergistic effect on birds (Nuñez \& Ferreira 2013, Mettifogo et al. 2014, Nuñez et al. 2015b). Nevertheless, these results show a high prevalence of enteric viruses circulating in Brazilian chicken flocks located in Minas Gerais.

The result that ANV was detected in $75 \%$ of the flocks differs from the results of previous reports for Brazil, where the same virus was found in $35.5 \%$ of turkey flocks Moura-Alvarez et al. 2013) and in $29.6 \%$ of chicken flocks tested (Mettifogo et al. 2014). This difference in results could be due to the different sources of diagnostic material used in these studies. While only faecal samples were analysed in previous works, the present study analysed homogenates from the intestine, pancreas and spleen from chickens showing signs of enteric diseases for the detection of viruses, based on the intracellular nature of the agent. This methodological difference could explain the higher detection rate in the present study for this and other viruses, including ART-A, CAstV and ChPV. However, despite the high incidence of ANV, it may not be the causative agent of the elevated mortality in these flocks because no visceral urate deposition or renal disturbances, which are classical lesions caused by pathogenic ANV, were noticed during necropsy (Siller et al. 1981). On the other hand, ART-A was detected in $68.75 \%$ of flocks $(11 / 16)$, and by contrast with what may have been expected, the pancreas was found to have the highest rate of infection, followed by the spleen; virus was detected in $100 \%$ and $91.7 \%$ of positive flocks, respectively. No virus was detected in the intestine. Studies in rats have shown the capacity of avian rotavirus to disseminate and replicate in different organs, such as the liver, spleen and pancreas; however, the mechanism by which rotavirus escapes the gastrointestinal tract and reaches other organs remains unknown (Crawford et al. 2006).

Affected RSS flocks were positive for CAstV and ChPV at equal rates ( $43.75 \%$ for both viruses). Previous surveys have also found that these pathogens circulate both in birds showing signs suggestive of RSS and in apparently healthy birds in Brazil (Moura-Alvarez et al. 2013, Mettifogo et al. 2014), United States (Pantin-Jackwood et al. 2008), and Poland (Domanska et al. 2014). Chicken astrovirus was also detected in one-day-old breeder chicks, indicating that vertical transmission may occur (Mettifogo et al. 2014). Moreover, parvoviruses have also been identified in day-old broiler chickens showing neurological signs, impaired mobility and diarrhoea, suggesting that these viruses may cause neurological disturbances in young chickens. The neurological disturbances that have been observed were characterized by cerebellar hypoplasia and hydrocephalus (Marusak et al. 2010). These findings suggest that both $C A s t V$ and ChPV may potentially be implicated in the aetiology and perpetuation of enteric disease and that pathogenicity and clinical signs may vary with the infecting strains.

No AReo and FAdV-1 were detected. These findings are in agreement with other results that show a low prevalence of these viruses (Moura-Alvarez et al. 2013, Mettifogo et al. 2014). These findings also support the hypothesis of
Decaesstecker et al. (1989) that AReo may not cause enteric disease, as these viruses do not exhibit pathogenicity when inoculated alone.

Viruses were most frequently detected in the pancreas, among the organs screened for enteric viruses. In general, the pancreas is an accessory organ of the gastrointestinal tract, and it has both endocrine and exocrine functions. The exocrine function of the pancreas is to produce and secrete several digestive enzymes, including trypsinogen, amylase, lipase and procarboxypeptidase, among others (Denbow 2000). In healthy birds, these enzymes are released into the ascending loop of the duodenum, thereby ensuring the digestion of lipids, carbohydrates and proteins in the diet (Osman et al. 1982, Horváthová et al. 2000). By contrast, flocks with characteristic signs of malabsorption syndrome may present alterations in the physiology of the exocrine pancreas. Previous studies have shown that birds with this syndrome exhibited diminished pancreatic amylase activity and changes in pancreatic protease levels (Szabo et al. 1989). Histological studies of pancreatic lesions in broilers with RSS revealed fibrosis, inflammation, vacuolar changes in the exocrine compartment, degeneration of acinar cells and loss of zymogen granules (Qamar et al. 2013). In pigeons, exocrine pancreas disease produced voluminous, coloured faeces and weight loss (Amann et al. 2006), and when aflatoxins are present in the diet, histological changes in the pancreas are observed, together with effects on performance and nutrient absorption (Marchioro et al. 2013). Together, these findings establish a relationship between pancreatic damage and signs of malabsorption, and, more importantly, a relationship between pancreatic damage and RSS.

In this study, malabsorption, enteritis and RSS in broilers associated with detection of CAstV, ANV, ART-A and ChPV were identified primarily in the pancreas, thereby suggesting that at least one of these pathogens may be implicated in insufficiency pancreatic, which may have led to the development of signs of malabsorption. However, no pathogen has yet been clearly determined to be a cause of these signs of illness in birds. Yet, in humans, rotavirus infection is known to produce increased secretion of pancreatic enzymes in some patients and to cause a moderately enlarged, oedematous pancreas (Giordano et al. 2013). Our hypothesis is that some rotavirus strains that usually infect mature, differentiated enterocytes of the small intestine could be escaping the gastrointestinal tract, thereby causing viremia, as shown in neonatal rat models by Crawford et al. (2006), and therefore could be affecting pancreatic tissue in birds. It must be taken into account that interactions with other enteric viruses may occur and that synergistic damage to the intestines, as well as to other organs, may happen concomitantly. We recommend specific viral challenges and pathologic assessments of viral replication using each of these enteric viruses to establish the aetiology of RSS. Our findings show that pancreatic tissue samples are an important source for the diagnosis of infection with enteric viruses in poultry. Finally, studies of experimental infections should be performed with isolated viruses to clarify the aetiology and pathogenesis of these viral infections associated with RSS. 
Acknowledgements.- This sudy was supported by grants received from $\mathrm{CNPq} \mathrm{n}^{\circ}$ 453920/2014-4, and FAPESP grant $\mathrm{n}^{\circ}$ 2013/08560-5. Antonio J. Piantino Ferreira is a recipient of CNPq fellowships.

\section{REFERENCES}

Amann O., Visschers M.J.M., Dorrestein G.M., WesterhoI F. \& Lumeij J.T. 2006. Exocrine pancreatic insufficiency in pigeons. Avian Pathol. 35:58-62.

Crawford S.E., Patel D.G., Cheng E., Hyser J.M., Ciarlet M., Finegold M.J., Conner M.E., Estes M.K. \& Berkova Z. 2006. Rotavirus Viremia and Extraintestinal Viral Infection in the Neonatal Rat Model. J. Virol. 80:4820-4832.

Day J.M., Spackman E. \& Pantin-Jackwood M.J. 2007. A multiplex RT-PCR test for the differential identification of turkey astrovirus type 1, turkey astrovirus type 2, chicken astrovirus, avian nephritis virus, and avian rotavirus. Avian Dis. 51:681-684.

Denbow M.D. 2000. Gastrointestinal anatomy and physiology, p.299-325. In: Whittow G.C. (Ed.), Sturkie's Avian Physiology. Academic Press, San Diego, CA.

Decaesstecker M., Charlier G., Peeters J. \& Meulemans G. 1989. Pathogenicity of fowl enteroviruses. Avian Pathol. 18:697-713.

Domanska K., Jacukowicz A., Bocian L. \& Minta Z. 2014. Astroviruses in Polish Commercial Turkey Farms in 2009-2012. Avian Dis. 58:158-164.

Giordano S., Serra G., Dones P., Di Gangi M., Failla M.C., Iaria C., Ricciardi F., Pernice L.M., Pantaleo D. \& Cascio A. 2013. Acute pancreatitis in children and rotavirus infection. New Microbiol. 36:97-101.

Horváthová V., Janeček Š. \& Šturdík E. 2000. Amylolytic enzymes: their specificities, origins and properties. Biol. Bratislava 55:605-615.

Koo B., Lee H., Jeon E., Jang H., Han M. \& Mo I. 2013. An unusual case of concomitant infection with chicken astrovirus and group A avian rotavirus in broilers with a history of severe clinical signs. J. Vet. Sci. 14:231-233.

Marchioro A., Mallmann O., Diel A., Dilkin P., Rauber R.H., Blazquez F.J.H., Oliveira M.G.A. \& Mallmann C.A. 2013. Effects of aflatoxins on performance and exocrine pancreas of broiler chickens. Avian Dis. 57:280-284.

Marusak R.A., Guy J.S., Abdul-Aziz T.A., West M.A., Fletcher O.J., Day J.M., Zsak L. \& Barnes H.J. 2010. PARTovirus-Associated Cerebellar Hypoplasia and Hydrocephalus in day old broiler chickens. Avian Dis. 54:156-160.

Mettifogo E., Nuñez L.F.N., Chacón J.L., Santander Parra S.H., Astolfi-Ferreira C.S., Jerez J.A., Jones R.C. \& Piantino Ferreira A.J. 2014. Emergence of enteric viruses in production chickens is a concern for avian health. Scient. World J. 2014:450423. <http://dx.doi.org/10.1155/2014/450423>

Meulemans G., Boschmans M., Berg T.P. \& Decaesstecker M. 2001. Polymerase chain reaction combined with restriction enzyme analysis for detection and differentiation of fowl adenoviruses. Avian Pathol. 30:655-660.

Moura-Alvarez J., Chacon J.L., Scanavini L.S., Nuñez L.F.N., Astolfi-Ferreira C.S., Jones R.C. \& Piantino Ferreira A.J. 2013. Enteric viruses in Brazilian turkey flocks: single and multiple virus infection frequency according to age and clinical signs of intestinal disease. Poult. Sci. 92:945-955.

Moura-Alvarez J., Nuñez L.F., Astolfi-Ferreira C.S., Knöbl T., Chacón J.L., Moreno A.M., Jones R.C. \& Ferreira A.J. 2014. Detection of enteric pathogens in Turkey flocks affected with severe enteritis, in Brazil. Trop. Anim. Health Prod. 46:1051-1058.
Nuñez L.F.N. \& Ferreira A.J.P. 2013. Viral agents related to enteric disease in commercial chicken flocks, with special reference to Latin America. World's Poult. Sci. J. 69:853-864.

Nuñez L.F., Parra S.H., Mettifogo E., Catroxo M.H., Astolfi-Ferreira C.S. \& Piantino Ferreira A.J. 2015a. Isolation of chicken astrovirus from specific pathogen-free chicken embryonated eggs. Poult Sci. 94:947-954.

Nuñez L.F., Santander Parra S.H., Mettifogo E., Astolfi-Ferreira C.S. \& Piantino Ferreira A.J. 2015b. Isolation and molecular characterisation of chicken pARTovirus from Brazilian flocks with enteric disorders. Brit. Poult. Sci. 56:39-47.

Nuñez L.F., Sá L.R.M., Parra S.H.S., Astolfi-Ferreira C.S., Carranza C. \& Piantino Ferreira A.J. 2016a. Molecular detection of chicken pARTovirus in broilers with enteric disorders presenting curving of duodenal loop, pancreatic atrophy, and mesenteritis. Poult. Sci. <http://dx.doi. org/10.3382/ps/pev439>

Nuñez L.F., Santander Parra S.H., Carranza C., Astolfi-Ferreira C.S., Buim M.R. \& Piantino Ferreira A.J. 2016b. Detection and molecular characterization of chicken astrovirus associated with chicks that have an unusual condition known as "white chicks" in Brazil. Poult. Sci. <http://dx.doi. org/10.3382/ps/pew062>

Otto P.H., Ahmed M.U., Hotzel H., Machnowska P., Reetz J., Roth B., Trojnar E. \& Johne R. 2012. Detection of avian rotaviruses of groups A, D, F and $\mathrm{G}$ in diseased chickens and turkeys from Europe and Bangladesh. Vet. Microbiol. 156:8-15.

Osman A.M. 1982. Amylase in chicken intestine and pancreas. Comp. Biochem. Physiol. 73:571-574.

Pantin-Jackwood M.J., Day J.M., Jackwood M.W. \& Spackman E. 2008. Enteric viruses detected by molecular methods in commercial chicken and turkey flocks in the United States between 2005 and 2006. Avian Dis. 52:235-244.

Qamar M.F., Aslam H. \& Jahan N. 2013. Histopathological studies on stunting syndrome in broilers, Lahore, Pakistan. Vet. Med. Int. 2013:1-6. DOI: 10.3382/ps/pev439

Rebel J.M., Balk F.R., Post J., Van Hemert S., Zekarias B. \& Stockhofe N. 2006. Malabsorption syndrome in broilers. World's Poult. Sci. J. 62:17-29.

Saif Y.M. 2013. Viral Enteric Infections, p.375-376. In: Swaine D.E., Glisson J.R., McDougald N.L.K., Suarez D.L. \& Nair V. (Eds), Diseases of Poultry. Wiley-Blackwell, Oxford, UK.

Siller W.G. 1981. Renal pathology of the fowl - a review. Avian Pathol. 10:187-262.

Szabo J., Salyi G. \& Rudas P. 1989. Effect of malabsorption syndrome on pancreatic function in broilers. Poult. Sci. 68:1553-1560.

Villarreal L., Uliana G., Valenzuela G., Chacon J.L., Saidenberg A., Sanches A., Brandão P.E., Jerez J.A. \& Ferreira A.J.P. 2006. Rotavirus detection and isolation from chickens with or without symptoms. Braz. J. Poult. Sci. 8:187-191.

Zsak L., Strother K.O. \& Day J.M. 2009. Development of a polymerase chain reaction procedure for detection of chicken and turkey parvoviruses. Avian Dis. 53:83-88.

Zsak L., Cha R.M. \& Day J.M. 2013. Chicken PARTovirus-induced runting-stunting syndrome in young broilers. Avian Dis. 57:123-127. 